\title{
Food Consumption Patterns of Adult Population in Rural and Urban Areas of Faizabad District of Uttar Pradesh, India
}

\author{
Pravisha Pandey ${ }^{1}$, Neerubala ${ }^{2}$ \\ ${ }^{1}$ Research Scholar, SHIATS, Allahabad, U.P., India \\ ${ }^{2}$ Associate professor, SHIATS, Allahabad, U.P., India
}

\begin{abstract}
Background: Poor dietary habit is widely recognized as an important risk factor in development of non- communicable disease (NCDs). This study was to provide a data on food consumption pattern existing among the adult population of Faizabad district, which has either negative or positive implication for nutritional deficiencies and NCDs. Methods: This study was a cross - sectional descriptive survey carried out in rural and urban area of Faizabad District. Total 400 respondents aged above 18 years were selected by simple random sampling. Two eligible participants of both sexes in each of the selected household were interviewed with a modified version of WHO stepwise questionnaires to obtain information on demographic and socioeconomic characteristics as well as food consumption patterns. Results: The mean age of the respondents were 35 years. Majority of urban populations (28.5\%)were businessman, while the participants from rural areas were predominantly farmers (47.5). $78.5 \%$ and $60 \%$ of both rural and urban respondents were belonging to vegetarian category respectively. Cereals consumption in rural and urban areas was quite similer in a month, it included mainly wheat and rice only, While the consumption of coarse grains was very low (2-3 days in a month). Consumption of pulses included red gram and green gram dhal had taking by rural population by 15-20 days in a month, while in urban population it was 10-15 days in a month. Only seasonal and low cost fruits were consumed by rural population while all type of fruits was consumed by urban population, but it was below 5 serving in a day. Consumption of leafy vegetables was 5-10 days in a month for both urban and rural population. The study revealed that low cost, easily available and staple foods was frequently consumed by rural population. Mustard oil was the commonest type of oil used in cooking food in rural area, while refined oil and soybean oil was frequently consumed by urban population. On other hand consumption of foods considered as less healthy such as fast foods/pastries, sweets, chocolates, soft-drinks were frequently consumed by urban population. Conclusions: Clearly focused nutrition education efforts should aimed to strengthening the positive trends and combating the negative ones can go a long way in improving the dietary intake, lifestyles and nutritional status of the population.
\end{abstract}

Keywords: Food consumption patterns, Adult population, Dietary habits, Faizabad District

\section{Introduction}

India is a vast and varied subcontinent, with $2.4 \%$ of its global landmass supporting over one-sixth of the world's population. At the time of independence the country had high poverty and under nutrition rates. Realizing the importance of rapidly improving the situation, the country invested in multi-sectoral, multi-pronged strategies and programs to improve nutritional status of the population. Nutrition scientists have utilized the data from ongoing nutrition surveys to assess trends in dietary intake and nutritional status and monitor progress and impact of ongoing nutrition and health interventions. Non communicable diseases are increasingly recognized as a major cause of morbidity and mortality worldwide.

Food consumed by an individual has a lot to do with the nutritional and health status of that individual.one major risk factor for NCDs is poor dietary intake, in addition to alcohol, tobacco and physical activity. Poor diet is reported to contribute $87 \%$ of high blood pressure in sub -saharian Africa.

A WHO/FAO report indicated that low in energy dense food and abundant in fruits, vegetables together with an active life style are among the key measure to combat chronic diseases similarly evidence shows that if the population adopts recommendations dietary behavior ,reduction in morbidity and mortality from diet related disease can be achieved.

The aim of study is to provide data on food consumption pattern existing among the adult population, which has either positive or negative implications for the NCDs. Findings revealed by the study will help to develop strategies that ensure healthy eating habits and ultimately the well being of the population.

There has been a decline in the proportion of expenditure on food items in last three decades in both urban and rural areas. The proportion of expenditure on non-food items has increased from $24 \%$ to $37.7 \%$. However, the expenditure on food remained higher in rural areas as compared to urban areas .Between 1972-73 and 2004-05, the share of food in total consumer expenditure has fallen from $73 \%$ to $55 \%$ in rural areas and from $64 \%$ to $42 \%$ in urban areas. The share of cereals has fallen from $41 \%$ of consumer expenditure to $18 \%$ in rural India and from $23 \%$ to $10 \%$ in urban India over the same period. The decline in consumption expenditure on food items has mainly due to low cost of cereals; in addition there has been a decline in cereal consumption especially among the middle and high-income group. Over years diet has become more diverse especially in the middle and upper income groups. In urban areas expenditure on vegetables, oil and sugar has decreased after $50^{\text {th }}$ round whereas in rural areas expenditure on vegetables had increased and 


\section{International Journal of Science and Research (IJSR) \\ ISSN (Online): 2319-7064}

Index Copernicus Value (2013): 6.14 | Impact Factor (2014): 5.611

expenditure on beverages has almost doubled. The percentage of households reporting milk consumption has grown in both rural and urban areas between 1993-94 and $2004-05$ by 5 percentage points $-66 \%$ to $71 \%$ in rural areas and $80 \%$ to $85 \%$ in urban areas. Per capita consumption of edible oil has risen over the eleven years following 1993-94 (50 ${ }^{\text {th }}$ round) by as much as $30 \%$ in rural India and about $18 \%$ in urban India. Over the same period the expenditure on beverages has nearly doubled from $2.4 \%$ to $4.5 \%$ in rural areas. The growing oil consumption is a matter of concern in view of the increasing over nutrition, diabetes and CVD risks factors. If the expenditure on beverages and tobacco are used for purchase of vegetables and fruits, there can be substantial benefit in terms of micronutrient intake. Dietary diversification and an increase in vegetable intake is the only sustainable method of improving micro nutrient status of the population. One of the major factors responsible for the low consumption of vegetables is the non-availability of vegetables; especially green leafy vegetables through out the year at an affordable cost both in urban and rural areas. Data from NNMB also shows that over this period there has not been any significant increase in the intake of vegetables and micro nutrients (vitamin - A, iron and folic acid). The Tenth Plan envisaged a paradigm shift from food security to nutrition security to meet the needs of macro, micro and phyto nutrients through dietary diversification. In order to ensure sustained increase in vegetable consumption, it is important to improve availability, affordability, access and awareness about the need for increased vegetable intake. Focus on cultivation of low cost vegetables at home and in wasteland areas can go a long way in meeting vegetable needs of rural poor. Horticulture products provide higher yield per hectare and are economically viable options for small farmers especially when backed up by appropriate storage, processing and transportation facilities. If sustained, it would also improve access to vegetables at an affordable cost throughout the year in urban and rural areas. A small increase in expenditure on vegetable and phytonutrient may ensure that there is increased vegetable consumption to meet the nutritional needs of the population.

In India, NSSO computes consumption pattern of foodstuffs at national, state and household level from the data on

expenditure on food and local cost of food. Data on consumption pattern of foodstuffs in the most recent quinquennial survey is presented here below.

In 2004-05, cereals formed the largest component of the diet. Consumption of pulses was very low; this is may be due to increasing prices of pulses. Consumption of milk, fruits and vegetables, and animal food continue to be quite low. Consumption of all foodstuffs increases with increasing income. This is especially true for sugar, oil, milk and animal products. Data from NNMB also indicate that energy consumption in highest income group is higher than the lower income groups. The higher energy intake combined with lower energy expenditure in these income groups' accounts for the observed increase in overweight and obesity especially in affluent segments of population.

\section{Methods and Material}

The study was based on simple random sampling and a part of village and town wise survey of food consumption patterns in Faizabad district of Uttar Pradesh. Twovillages in rural areas named Sarai-Dhanethi and Anjrauli, two towns in urban areas named Kaushalpuri colony, Shivpuri colony was selected for the study.

The study population was consisted of adults, 18 years to 49 years. Who resided in the selected places at the time of survey.200 from rural area and 200 from urban area was recruited by simple random sampling. Last stage in collection of data was the selection of two eligible respondents of both sexes from every household within the selected enumeration area.

Data was collected from the pretested and predesigned questionnaire. Information obtained included demographic and socio-economic characteristics as well as a 7 days dietary recall where participants were asked how often they consumed specific foods. Frequencies, percentage, means were analyzed.

\section{Results}

Table 1: Demographic characteristics of respondents

\begin{tabular}{|c|c|c|c|c|c|c|c|}
\hline \multicolumn{2}{|c|}{ Variable } & \multicolumn{2}{|c|}{ Rural } & \multicolumn{2}{|c|}{ Urban } & \multicolumn{2}{|c|}{ Total \% } \\
\hline & & Male & female & Male & female & Male & female \\
\hline \multirow[b]{3}{*}{ Age } & $18-29$ years & 36 & 40 & 37 & 32 & 38.21 & 34.44 \\
\hline & $30-39$ years & 39 & 41 & 37 & 33 & 39.79 & 35.40 \\
\hline & $40-49$ years & 20 & 24 & 22 & 39 & 21.98 & 30.14 \\
\hline \multirow[b]{2}{*}{ Sex } & Male & 95 & - & 96 & - & 47.75 & - \\
\hline & Female & 105 & - & 104 & - & - & 52.25 \\
\hline \multirow{4}{*}{ Education } & Primary & 55 & 28 & 10 & 19 & 34.03 & 47.47 \\
\hline & Secondary & 64 & 22 & 18 & 34 & 33.50 & 26.79 \\
\hline & Graduate & 20 & 5 & 45 & 28 & 34.03 & 15.78 \\
\hline & Post graduate & 5 & 1 & 28 & 18 & 17.21 & 9.0 \\
\hline \multirow{4}{*}{ Family income/m } & Below 10,000/- & \multicolumn{2}{|c|}{$\frac{1}{74}$} & \multicolumn{2}{|c|}{-} & \multicolumn{2}{|c|}{$\frac{1}{18.5}$} \\
\hline & $10000-30,000 /-$ & \multicolumn{2}{|c|}{89} & \multicolumn{2}{|c|}{79} & \multicolumn{2}{|c|}{42} \\
\hline & $30000-50,000 /-$ & \multicolumn{2}{|c|}{25} & \multicolumn{2}{|c|}{91} & \multicolumn{2}{|c|}{29} \\
\hline & Above $50,000 /-$ & \multicolumn{2}{|c|}{12} & \multicolumn{2}{|c|}{30} & \multicolumn{2}{|c|}{10.5} \\
\hline \multirow{3}{*}{ Occupation } & Farmer & 95 & - & - & - & \multicolumn{2}{|c|}{23.75} \\
\hline & Teacher & - & 5 & 12 & 8 & 6.28 & 6.22 \\
\hline & Businessman & 30 & - & 36 & - & 34.55 & - \\
\hline
\end{tabular}

Volume 5 Issue 2, February 2016 www.ijsr.net 
International Journal of Science and Research (IJSR)

ISSN (Online): 2319-7064

Index Copernicus Value (2013): 6.14 | Impact Factor (2014): 5.611

\begin{tabular}{|c|c|c|c|c|c|c|c|}
\hline & Other & 75 & 100 & 48 & 96 & 64.39 & 93.77 \\
\hline \multirow{3}{*}{ Physical activity } & Sedentary & 15 & 26 & 65 & 92 & 41.88 & 56.45 \\
\cline { 2 - 8 } & Moderate & 22 & 42 & 28 & - & 26.17 & 20.09 \\
\cline { 2 - 8 } & Heavy & 58 & 37 & 7 & 13 & 34.03 & 23.92 \\
\hline \multirow{3}{*}{ Food habits } & Vegetarian & 75 & 82 & 55 & 65 & 68.06 & 70.33 \\
\cline { 2 - 8 } & Non-vegetarian & 15 & 15 & 36 & 30 & 26.17 & 21.53 \\
\cline { 2 - 8 } & Ovotarian & 5 & 8 & 5 & 10 & 5.23 & 4.78 \\
\hline \multirow{3}{*}{ Body mass index } & $>40$ & - & - & - & 11 & - & 5.26 \\
\cline { 2 - 8 } & $30-40$ & - & 6 & 12 & 32 & 6.28 & 18.18 \\
\cline { 2 - 8 } & $25-29.9$ & 15 & 67 & 11 & 46 & 13.61 & 54.06 \\
\cline { 2 - 8 } & $<25$ & 80 & 32 & 73 & 17 & 80.10 & 23.44 \\
\hline
\end{tabular}

Table 2: Average days of consumption of food groups in a month

\begin{tabular}{|c|c|c|c|}
\hline Food groups & Rural & Urban & Average \\
\hline \multicolumn{4}{|c|}{ Cereals } \\
\hline Wheat & 30 & 30 & 30 \\
\hline Rice & 28 & 26 & 27 \\
\hline Barley & 1 & 3 & 2 \\
\hline Pearl millet & nil & nil & \\
\hline Maize & 6 & 4 & 5 \\
\hline Other & nil & 2 & 2 \\
\hline \multicolumn{4}{|c|}{ Pulses } \\
\hline Red gram & 24 & 20 & 22 \\
\hline Green gram & 3 & 4 & 3.5 \\
\hline Horse gram & 4 & 4 & 4 \\
\hline Lentil & 1 & 2 & 1.5 \\
\hline Other & 3 & 8 & 5.5 \\
\hline \multicolumn{4}{|c|}{ Vegetable A ( in season) } \\
\hline Leafy vegetables & 17 & 21 & 19 \\
\hline Other & 22 & 26 & 24 \\
\hline \multicolumn{4}{|c|}{ Vegetable B ( in season) } \\
\hline Potato & 24 & 12 & 18 \\
\hline Onion & 26 & 26 & 26 \\
\hline peas & 14 & 18 & 16 \\
\hline carrot & 2 & 8 & 5 \\
\hline other & 10 & 17 & 13.5 \\
\hline \multicolumn{4}{|c|}{ Fruits ( in season) } \\
\hline Guava & 3 & 2 & 2.5 \\
\hline Banana & 1 & 4 & 2.5 \\
\hline Mango & 20 & 25 & 22.5 \\
\hline Apple & - & 3 & 1.5 \\
\hline Other & 4 & 10 & 7 \\
\hline \multicolumn{4}{|c|}{ Milk \& milk product } \\
\hline Milk & 22 & 26 & 24 \\
\hline Butter milk & 5 & 4 & 4.5 \\
\hline Curd & 3 & 6 & 4.5 \\
\hline Cheese & - & 1 & 1 \\
\hline \multicolumn{4}{|c|}{ Fats \& Oils } \\
\hline Mustard oil & 30 & 28 & 29.5 \\
\hline Soya bean oil & - & - & - \\
\hline Refined oil & 1 & 2 & 1.5 \\
\hline Ghee /butter & 4 & 2 & 3 \\
\hline Egg & & & \\
\hline \multicolumn{4}{|c|}{ Flesh food } \\
\hline Chicken & 1 & 3 & 2 \\
\hline Fish & 1 & 3 & 2 \\
\hline Mutton & - & 1 & 1 \\
\hline
\end{tabular}

Volume 5 Issue 2, February 2016 www.ijsr.net 


\section{International Journal of Science and Research (IJSR) \\ ISSN (Online): 2319-7064}

Index Copernicus Value (2013): 6.14 | Impact Factor (2014): 5.611

Table 3: Patterns of consumption of protein, carbohydrate and fat rich diet

\begin{tabular}{|c|c|c|c|c|c|c|c|c|c|c|}
\hline \multicolumn{11}{|c|}{ Protein rich food } \\
\hline \multirow{3}{*}{ Food type } & \multirow{2}{*}{\multicolumn{2}{|c|}{ Cereals }} & \multirow{2}{*}{\multicolumn{2}{|c|}{ Pulses }} & \multicolumn{4}{|c|}{ Animal product } & \multirow{2}{*}{\multicolumn{2}{|c|}{ Nuts }} \\
\hline & & & & & & & & food & & \\
\hline & Rural & urban & Rural & urban & Rural & urban & Rural & urban & Rural & urban \\
\hline Always & 200 & 200 & 150 & 120 & 110 & 95 & - & - & - & - \\
\hline Often & - & - & 50 & 60 & 36 & 38 & 9 & 25 & - & 10 \\
\hline Sometimes & - & - & - & 20 & 24 & 22 & 8 & 30 & 25 & 175 \\
\hline Rarely & - & - & - & - & 7 & 15 & 21 & 10 & 100 & 15 \\
\hline Never & - & - & - & - & 23 & 30 & 157 & 120 & 75 & - \\
\hline
\end{tabular}

CHO rich diet

\begin{tabular}{|c|c|c|c|c|c|c|c|c|}
\hline \multirow{2}{*}{ Food type } & \multicolumn{2}{|c|}{ Potato } & \multicolumn{2}{c|}{ Sugar } & \multicolumn{2}{c|}{$\begin{array}{c}\text { Roots \& } \\
\text { tubers }\end{array}$} & \multicolumn{2}{c|}{$\begin{array}{c}\text { Fruits \& } \\
\text { other veg. }\end{array}$} \\
\cline { 2 - 10 } & Rural & urban & Rural & urban & Rural & urban & Rural & urban \\
\hline Always & - & - & 78 & 110 & 58 & 65 & 25 & 64 \\
\hline Often & 176 & 147 & 91 & 65 & 104 & 110 & 145 & 132 \\
\hline Sometimes & 15 & 35 & 24 & 25 & 38 & 25 & 30 & 13 \\
\hline Rarely & 3 & 5 & - & - & - & - & - & - \\
\hline Never & 6 & 13 & 7 & 14 & - & - & - & - \\
\hline
\end{tabular}

Fat rich diet

\begin{tabular}{|c|c|c|c|c|c|c|c|c|}
\hline \multirow{2}{*}{ Food type } & \multicolumn{9}{|l|}{ Mustard oil } & \multicolumn{2}{l|}{ soybean oil } & \multicolumn{2}{c|}{ Ghee } & \multicolumn{2}{c|}{$\begin{array}{c}\text { Nuts \& oil } \\
\text { seeds }\end{array}$} \\
\cline { 2 - 10 } & Rural & urban & rural & urban & Rural & urban & Rural & urban \\
\hline Always & 200 & 158 & - & 68 & 25 & 11 & - & - \\
\hline Often & - & 27 & - & 26 & 33 & 31 & - & 44 \\
\hline Sometimes & - & 15 & 13 & 19 & 71 & 110 & 25 & 22 \\
\hline Rarely & - & - & 8 & 17 & 45 & 11 & 69 & 110 \\
\hline Never & - & - & 179 & 70 & 26 & 37 & 106 & 24 \\
\hline
\end{tabular}

Table 4: Dietary change made by respondents in last one year

\begin{tabular}{|l|c|c|c|}
\hline Variable & Rural & Urban & Total \\
\hline Eat less sugar & 15 & 55 & $70(17.5 \%)$ \\
\hline Eat less salt & 10 & 42 & $52(13 \%)$ \\
\hline Eat more fruits & 17 & 32 & $49(12.25 \%)$ \\
\hline Eat more fibrous vegetables & 9 & 55 & $64(16 \%)$ \\
\hline Eat weight reducing diet & - & 42 & $42(10.5 \%)$ \\
\hline Do more exercise & 5 & 33 & $38(9.5 \%)$ \\
\hline
\end{tabular}

\section{Discussion}

The mean age of the respondents was 35 years in both rural and urban areas. Majority of both male and female had secondary education. The respondents mainly were occupation farmers in rural and businessman in urban areas. $78.5 \%$ and $60 \%$ of both rural and urban respondents were belonging to vegetarian category respectively. A large number of urban females were suffering from obesity in comparison to women of rural areas, as they are more physically active in comparison to women of urban areas.

Cereal consumption in both rural and urban areas was equal but the consumption of coarse cereals in urban areas is higher, although it was low in both areas.

In pulses consumption red gram dhal was very commonest among all in both areas while other pulses is frequently used 3-5 days in a month.it includes horse gram, green gram and moong dhal.

Consumption of leafy vegetables is higher in rural population as it not so costly and easily available, but in urban population people are attracted toward increasing the consumption of green leafy vegetables because it is very helpful in preventing non-communicable diseases.

Consumption of vegetables B group onion and potato consumption was higher in both areas; it was frequently consumed in low income group with frequency of 28 days in a month.

Fruits consumption in both areas was very low, because of their high cost but consumption of seasonal fruits like guava and mango was high in rural areas.

Fats and oils consumption includes ghee and mustard oil was highly consumed by rural population in comparison to urban population whereas the consumption of refined oil and soybean oil is higher in urban areas.

On the other hand the consumption of foods considered as less healthy such as fast foods/pastries, sweets, chocolates and soft drinks was higher in urban areas. Both populations were depending on staple foods which are not so costly and easily available. About $40 \%$ of total populations from rural and urban were taking inappropriate diet, their diet are insufficient in meeting all important macro and micronutrients.

\section{Conclusion}

Clearly focused nutrition education efforts should aimed to strengthening the positive trends and combating the negative ones can go a long way in improving the dietary intake, lifestyles and nutritional status of the population.

\section{References}

[1] Blandford, David.1984. Changes in Food Consumption Patterns in the OECD Area," European Review of Agricultural Economics Vol. 11, pp. 43-65.

[2] Chalfant, James A. and Julian M. Alston, 1988. Accounting for Changes in Tastes." Journal of Political Economy, 96: 391-410.

[3] Clark, Gregory, Michael Huberman and Peter H. Lindert, 1995. A British Food Puzzle, 1770-1850, Economic History Review, 48 (2): 215-37.

[4] Cook, Roberta. 1990 Challenges and Opportunities in the U.S. Fresh Produce Industry, Journal of Food Distribution Research. February: 67-74.

[5] Cranfield, John A.L., Thomas W. Hertel, James E. Eales, and Paul V. Preckel, 1998. Changes in the Structure of Global Food Demand, American Journal of Agricultural Economics, 80 (5): 1042-1050. 


\section{International Journal of Science and Research (IJSR) \\ ISSN (Online): 2319-7064}

Index Copernicus Value (2013): 6.14 | Impact Factor (2014): 5.611

[6] Delisle, Hélène 1990. Patterns of Urban Food Consumption in Developing Countries: Perspective from the 1980's, ftp.fao.org, assessed on 30.11.09

[7] FAO State of World Food Security, FAO Rome -2007

[8] Haley Mildred M, 2001. Changing Consumer Demand for Meat: The U.S Example, 19702000 in Changing Structure of Global Food Consumption and Trade, Regmi, A. (ed.), Available at www.ers.usda.gov

[9] Huang, Jikun, and Cristina C. David, 1993. Demand for Cereal Grains in Asia: The Effect of Urbanization, Agricultural Economics, 8:107-124.

[10] Kennedy, Eileen and Thomas Reardon, 1994. Shift to Nontraditional Grains in the Diets of East and West Africa: Role of Women's Opportunity Cost of Time, Food Policy, 1: 45-56.

[11] Moschini, G., and K.D. Meilke, 1989. Modeling the Pattern of Structural Change in U.S. Meat Demand.American Journal Agricultural Economics, 71: 253-61.

[12] National Sample Survey Organization: NSSO surveys 1973

http://mospi.nic.in/mospi_nsso_rept pubn.htm; last accessed on $4 / 3 / 0$

[13] NNMB National Nutrition Monitoring Bureau. 19792002. NNMB Reports: National Institute Of Nutrition, Hyderabad

[14] National Accounts Statistics, CSO: http://mospi.nic.in/mospi_cso_rept_pubn.htm; last accessed on 24/09/07

[15] National Family Health Survey (NFHS-3): http://mohfw.nic.in/nfhsfactsheet.htm; last accessed on 24/09/07

[16] National Sample Survey Organisation: http://mospi.nic.in/mospi_nsso_rept_pubn.htm; last accessed on $24 / 09 / 07$

[17] Nayga, Rodolfo M. Jr., 1995. Determinants of U.S. Household Expenditures on Fruit and

[18] Vegetables: A Note and Update, Journal of Agriculture and Applied Economics, 27: 588-594.

[19] Pollack Susan L., 2001, Consumer Demand for Fruit and Vegetables: The U.S. Example, In Changing Structure of Global Food Consumption and Trade, Regmi, A. (ed). Op.cited. Pp.18-26

[20] Reardon, Thomas, 1993. Cereals Demand in the Sahel and Potential Impacts of RegionalCereals Protection, World Developments, 21 (1): 17-35.

[21] Regmi, Anita M.S. Deepak, James L. Seale Jr., Jason Bernstein1, 2001. Cross-Country Analysis of Food Consumption Patterns in Changing Structure of Global FoodConsumption and Trade, Regmi, A. (ed). Op.cited.pp.18-26

[22]Regmi Anita and Dyck John, 2001. Effects of Urbanization on Global Food Demand in Changing Structure of Global Food Consumption and Trade, Regmi, A. Op.cited: 27-34.

[23] Reynolds, Anderson, 1990. Analyzing Fresh Vegetable Consumption From Household Survey Data, Southern Journal of Agricultural Economics, December: 31-38.

[24] Senauer, Ben, David Sahn, and Harold Alderman, 1986. The Effect of the Value of Time on Food Consumption Patterns in Developing Countries: Evidence from Sri Lanka, American Journal of Agricultural Economics, 68: 920-927.
[25] Theil, Henri, Ching-Fan, Chung and James L. Seale, 1989. Jr. International Evidence on Consumption Patterns, Greenwich, CT: JAI Press Inc. 